\title{
MIĘDZYNARODOWY PROJEKT BADAWCZY DWIE ARCHAICZNE SEOWIAŃSKIE WYSPY JEZZYKOWE I KULTUROWE: POLESIE I RODOPY
}

\author{
Feliks Czyżewski, Petar Sotirov, \\ AgnieszKa DudeK-SzumigaJ \\ Uniwersytet Marii Curie-Skłodowskiej w Lublinie
}

Projekt związany jest z badaniami i promowaniem dwóch regionów europejskich - Polesia i Rodopów. Zainteresowanie tymi regionami i przystąpienie do wspólnych badań zdaje się uzasadnione z wielu powodów. Obydwa regiony są podobne pod względem swojej lokalizacji - obejmują one tereny przynależące do różnych państw. Polesie leży na terenach pogranicznych między Polską, Ukrainą i Białorusią, Rodopy zaś - to pasmo górskie na Bałkanach na pograniczu między Bułgarią a Grecją, między dolinami rzek Mesta i Marica.

Wspomniane dwa europejskie regiony uważane są wśród naukowców slawistów za unikalne pod względem występujących tutaj zjawisk językowo-kulturowych. Obydwa regiony zamieszkiwane były bardzo wcześnie przez Słowian i wiele cech języka i kultury tutejszej ludności prezentuje bardzo archaiczny stan słowiańskiego języka i kultury.

Konserwacja języka i kultury na Polesiu i Rodopach ma różne powody i podstawy. Rodopy, które zostały zaludnione przez Słowian już w VI wieku, odróżniają się bardzo specyficzną lokalizacją (pograniczne pasmo górskie) i historią. Miały miejsce tutaj ważne wydarzenia historyczne, które w dużym stopniu również przyczyniły się do językowo-kulturowej konserwacji. Na przykład podczas panowania osmańskiego (XIV-XIX w.) toczyła się tutaj ostra walka między chrześcijaństwem a islamem. W jej wyniku część mieszkańców regionu uległa islamizacji. Konserwacja archaicznych cech w języku i kulturze chrześcijańskiej ludności terenu odzwierciedla jej dążenie do zachowania tożsamości chrześcijańskiej. Teren Rodopów prezentuje szereg archaicznych cech w zakresie języka, szczególnie zjawiska o charakterze dialektologii, onomastyki i etnolingwistyki, oraz w dziedzinie folkloru, które podkreślano już w licznych publikacjach.

Polesie, które w świetle badań naukowych uznawane jest przez znaczą część naukowców za prakolebkę Słowiańszczyzny, również stanowi niezwykle ważny obiekt dociekań 
naukowych. Badania na tym obszarze Słowiańszczyzny szczególnie intensywnie i zarazem kompleksowo, z zastosowaniem jednolitej metody, prowadzone są od lat 6o. XX w. przez zespół moskiewski pod kierunkiem Nikity Tołstoja, następnie Swietłany Tołstojowej. Wyniki i metoda szkoły moskiewskiej znane są w środowisku lubelskim, a podjęta przed kilku laty zespół etnolingwistyczny przy Wydziale Humanistycznym UMCS nawiązuje do doświadczeń etnolingwistów wschodniosłowiańskich i polskich wyniesionych z prac nad Atlasem kultury i języka pogranicza polsko-białorusko-ukraińskiego. Obecnie, wychodząc z określonego doświadczenia metodyki prac nad problemami pogranicza językowego, pragniemy zainicjować prowadzenia kolejnych badań nad Polesiem równolegle i w zestawieniu z drugim archaicznym obszarem słowiańskim - Rodopy na pograniczu bułgarsko-greckim.

Mimo licznych badań naukowych przeprowadzonych na terenach Polesia i Rodopów nadal duża część problematyki języka i kultury tych regionów jest nie prześwietlona. Zasługuje na uwagę również fakt, iż większa część dotychczasowych badań wykonywana była przez jednonarodowe zespoły badawcze, prezentujące tylko jedno państwo, a wyniki nie były zestawiane, porównywane lub konfrontowane. Dotyczy to przede wszystkim badań Rodopów. Przystąpienie Bułgarii do Unii Europejskiej daje możliwość naprawienia tego problemu.

Jako uzasadnienie proponowanego projektu można wysunąć jeszcze fakt, iż wyniki badań nad odrębnymi słowiańskimi obszarami prezentującymi archaiczne zjawiska językowo-kulturowe też nie były konfrontowane między sobą, a taka konfrontacja miałaby ważne znaczenie dla rekonstrukcji języka i kultury najstarszych Słowian. W związku z tym uważamy za stosowne przystąpienie do badań porównawczych na terenach Polesia i Rodopów.

Wreszcie trzeba podkreślić, iż wspomniane regiony, mimo że prezentują archaiczne i unikatowe słowiańskie zjawiska językowe i kulturowe, są w niewystarczającym stopniu promowane i znane w szerszym gronie mieszkańców Europy i świata. Dlatego projekt przewiduje nie tylko badania, ale również rozpowszechnienie wyników przeprowadzonych badań za pomocą techniki tradycyjnej i wirtualnej.

Obiektem badawczym projektu są zjawiska o charakterze językowym i kulturowym na obszarach regionów Polesia i Rodopów. Pod uwagę przy badaniach brana jest problematyka etnolingwistyczna (ludowe nazwy elementów bytu i kultury, np. nazwy narzędzi, świąt, obrzędów, roślin, zwierząt i inne), dialektologiczna (badania nad najbardziej archaicznymi cechami zachowanymi w gwarach Polesia i Rodopów), onomastyczna (badania słowiańskiej warstwy antroponimicznej, toponimicznej i zoonimicznej), socjolingwistyczna (badania sytuacji językowej na terenach Polesia i Rodopów w aspekcie diachronicznym i synchronicznym). 
Projekt ma charakter referencyjno-badawczy, dlatego część jego celów ma znamiona popularyzatorskie, druga zaś związana jest z pracą naukowo-badawczą. Projekt przewiduje realizację następujących zamierzeń:

1. Ujawnienie i zarejestrowanie najbardziej archaicznych słowiańskich zjawisk językowych i kulturowych zachowanych na „wyspach” Polesie i Rodopy w celu ich ochrony (ekologia lingwistyczno-kulturowa);

2. Rozpowszechnienie wyników badań, prezentacja ich w postaci książek, albumów, filmów, produktów techniki wirtualnej, pokazanie zbadanych zjawisk jako językowego i kulturowego dziedzictwa Słowian, promocja Polesia i Rodopów jako archaicznych wysp słowiańskiego języka i kultury;

3. Skonfrontowanie wyników badań dokonanych na terenie Polesia z wynikami badań na terenie Rodopów w celu wyciągnięcia wniosków dotyczących stanu języka i kultury Prasłowian.

Przeprowadzone badania i ich wyniki lingwistyczne i ekstralingwistyczne stanowić będą, jak sądzimy, przyczynek do wiedzy w zakresie rekonstrukcji kultury duchowej Prasłowian. Pozyskane materiały zgromadzone zostaną w zbiorach kartoteki Instytutu Filologii Słowiańskiej i utrwalone na elektronicznych nośnikach (baza danych).

Projekt ma powiązania z aktualnie prowadzonymi w Polsce (UMCS) i ośrodkach zagranicznych (Uniwersytet Brzeski, Uniwersytet Wołyński, Uniwersytet Płowdiwski - filia w Smolan) badaniami w zakresie etnolingwistyki. Realizowane dotychczas zadania badawcze, m.in. prace nad Atlasem etnolingwistycznym Pobuża', mają ważne znaczenie w rozwiązywaniu problemów teoretycznych, jak i w zakresie ustalenia metodyki badań terenowych.

Od roku 2010 wyniki prac prezentowane są na posiedzeniach zespołów międzynarodowych i planowanych konferencjach w Polsce i w Bułgarii oraz w postaci artykułów naukowych opublikowane są w wydawnictwach krajowych i zagranicznych. Głównym realizatorem projektu są pracownicy Instytutu Filologii Słowiańskiej Uniwersytetu Marii Curie-Skłodowskiej w Lublinie (Polska) we współpracy z przedstawicielami Filii Uniwersytetu Płowdiwskiego w Smolyanie (Bułgaria), Trackiego Uniwersytetu Demokryta w Komotini (Grecja) i Uniwersytetu im. A. S. Puszkina w Brześciu (Białoruś).

1 Zob. Jan Adamowski, Jerzy Bartmiński, Feliks Czyżewski, Atlas etnolingwistyczny Pobuża (projekt), [w:] Język i kultura na pograniczu polsko-ukraińsko-biatoruskim, red. Feliks Czyżewski. Lublin: Instytut Europy Środkowo-Wschodniej, 2001 (Seria Wydawnicza Lubelskiego Konwersatorium Pogranicze; t. 3).; również Michał Sajewicz, Koncepcja Atlasu etnolingwistycznego Pobuża. - Acta Polono-Ruthenica 1, red. A. Bartoszewicz, Olsztyn: Wydawnictwo WSP w Olsztynie, 1996, 325-332. 